\title{
Monism and dividualism in Meister Eckhart
}

\section{Big Bang - monism and division}

According to my former co-fellow of King's College, Cambridge, the astronomer Martin Rees, 'our universe sprouted from an initial event, the "big bang".' ${ }^{1}$ Not the concept of this event itself, he sees as problematic, ${ }^{2}$ but the real challenge he sees in a unified interpretation of 'electric, nuclear and gravitational forces as different manifestations of a single primeval force'. ${ }^{3}$ He maintains this primeval force and the big bang, even though he moves away from the idea of a single universe to embrace the more recent concept of multiple universes, each with its own big bang, a conceptual shift, he thinks, that is as radical 'as the shift from pre-Copernican ideas to the realisation that the Earth is orbiting a typical star on the edge of the Milky Way, itself just one galaxy among countless others. ${ }^{.4}$ In his follow-up book, Just Six Numbers, Rees describes what he calls the 'especially significant' numbers, of which two 'fix the property of space', and another in particular captures 'the seeds for all cosmic structures [...] all imprinted in the Big Bang', the number on which 'the fabric of our universe depends'. ${ }^{5}$ Of course, as little as Rees wanted to invade the space of theologians and philosophers, so as little I'd like to tread on the grounds of astronomers and mathematicians which are extremely unfamiliar to me. Yet, it is interesting to note that while Rees sees the biggest move in his own approach as his shift away from an older universal monism, he is still wrestling with the idea of 'a single primeval force' - which he

1 Rees 1997, 1.

2 Ibid. 2: 'I would bet at least ten to one that there was indeed a big bang: that everything in our observable universe started as a compressed fireball'.

3 Ibid. 3.

4 Ibid.

5 Rees 1999, 3.

Note: Research for this paper was supported by a major research grant of the AHRC on 'Meister Eckhart and Paris University in the early 14th century' (2012-2016) (Reference AH/K002066/1), and its team (Chris Wojtulewicz, Maria O'Connor, Ian Richardson, Andrés Quero-Sanchez, Jana Ilnicka, Dietmar Mieth, Julie Casteigt, with Oliver Davidson as Co-I and me as PI); the research team was based at the Max Weber Centre for Advanced Cultural and Social Studies, University of Erfurt; research was further supported by a major research grant from the Austrian Science Fund (FWF) on 'Meister Eckhart's early Parisian Questions in context' and its team (Christian Jung, Dietmar Mieth and myself). 
does not substantially challenge, but only complements by other forces (captured in the essential numbers) that are seen as manifestations of the one primeval force, and by multiplying the idea of the product of the one force through the assumption of multiple Big Bangs and universes.

Moving back from contemporary astrophysics into past philosophy and theology, we will see that Meister Eckhart (before 1260 - 1328) had conceptualised the first principle in another revolutionary way which might be compared with the Copernican turn, but in which he remained a loner. As I will show in this contribution, he thought of the first principle not as a unique, primeval force, monistic power or single divine Godhead, but as a dividual transcendental cause. Although this idea can already be found in his known Latin works, ${ }^{6}$ two recent manuscript re-discoveries allow us to gain a novel insight into this view which Eckhart had presented both to his scholarly audience at Paris in Latin and again to a lay-audience in the vernacular.

In these manuscripts, as I will detail below, we find core texts, in the form of Quaestiones on the topic of 'relatio', that seem to go back to a lost collection of Quaestiones that Eckhart presented at the University of Paris in the years 1311/1313 when, for the second time, he held the chair of theology - a post reserved for foreigners, and an honour which prior to him was only granted to Thomas Aquinas.

At the opening of the vernacular Quaestio, Eckhart's interlocutors are portrayed as theologians who represent the long Christian (and Western non-Christian) tradition, according to which the first principle was equally a single principle and monotheism taken in the numerical sense ('Our God is one God'; 'Do not worship another God beside me'). Consequently, the interlocutors saw in the single Godhead the ontological basis, the one God and Father, within which, according to the ecclesial tradition, the Trinity of Father, Son and Spirit were rooted, but both the generation of the trinitarian persons of Son and Spirit, and the production of this world were reserved for the Father in his generative and creative activity. The Father's divine essence, the single Godhead, was seen as transcendant and beyond generation and creation. Just as with Rees and the one primeval force, the masters of Eckhart's time could not conceive of an essentially non-monistic first principle. In this regard, Eckhart developed a contrasting model of the first principle which to him was not only a theological or philosophical tenet, but - on the basis of his assumed interrelationship between natural sciences and ethical, philosophical and theological knowledge - was also seen by him as an alternative model that explains not only the generation of the Trinity, but equally the creation of the universe.

6 See Wojtulewicz 2017. 


\section{The discovery of Eckhart's Quaestiones on 'relation'}

Since the first edition of Eckhart's vernacular works by Franz Pfeiffer from the year 1851, we have known of a vernacular Quaestio by the Dominican master on 'relatio'. Yet - because Pfeiffer had taken this text out of its context and, together with other excerpts that he made from a soon later lost manuscript, placed and understood this text as one of a series of 'Sayings' ('Sprüche') ${ }^{7}$ which by scholars were seen as ambiguous, dubious or inauthentic material - the text had not attracted any attention. This has now changed for three reasons.

First, in 2010 I made the re-discovery of a set of four Parisian Questions by Meister Eckhart 'On the attributes [of God]', to which was added the summary of a further Quaestio unearthed by Walter Senner ${ }^{8}$, and which are now all published by Loris Sturlese in a supplement to the critical edition of Eckhart's works in the Kohlhammer edition ${ }^{9}$ with a joint German translation. ${ }^{10}$

Second, as the last two of these re-discovered Quaestiones (now Quaestiones Parisienses VIII and IX) deal with 'Relation' and 'Difference', my attention was drawn to the afore-mentioned vernacular Quaestio of Eckhart on 'relatio' and I asked myself how this vernacular text relates to the re-discovered Latin Quaestiones on the same topic of 'relation'.11

Third, and most importantly, by chance and scholarly attention, the famous manuscript ' $P$ ' (dated to the 1320s) had recently re-appeared, which contains the vernacular Quaestio on 'relatio', and parallels the same text as preserved

7 Pfeiffer 1857, 606-14, nn. 31-48.

8 Vinzent 2012, 156-86; the previously already known and recognized Parisian Questions can be found in the critical edition by Bernhard Geyer in Meister Eckhart, Die Lateinischen Werke (hereafter $L W$ ), V 27-83; English translation of these previously known questions in Maurer 1974. 9 Sturlese 2011 and the added fragment of a Question, found by Pater Walter Senner, which was initially edited and translated in the mentioned article in Vinzent 2012, now published by Sturlese 2011, 488.

10 Sturlese 2015; further studies on the new Parisian Questions have already been published or are under way: Vinzent 2015; Vinzent 2016; Mieth 2017a; Ian Richardson, Meister Eckhart's Parisian Question on God's omnipotence, Eckhart: Texts and Studies (forthcoming); Jana Ilnicka, Meister Eckhart's Parisian Questions on Relation and Difference, Eckhart: Texts and Studies (forthcoming); Markus Vinzent, Meister Eckhart's Parisian Question on Absolute and Directed Power, Eckhart: Texts and Studies (forthcoming).

11 This topic has been picked up by Jana Ilnicka for her $\mathrm{PhD}$ thesis which received the Erfurt University Prize, 2019. For an English publication of her results see the note before. 
in a Berlin manuscript (with some fragments in a Munich manuscript). ${ }^{12}$ When Pfeiffer made his excerpts, ' $\mathrm{P}$ ' belonged to a private collection at Giessen, Germany $^{13}$; it was subsequently sold to the architect Hugo von Ritgen who restored the Wartburg Castle, close to Eisenach, Germany, in the late 19th century, and as a gift by the architect became one of the medieval props of von Ritgen's restoration project. Since 1909 the codex was thought to have been lost, ${ }^{14}$ but in 2015 it turned up again in the small collection of manuscripts of the Wartburg. It was Balázs J. Nemes who was able to identify the manuscript, after he came to know of its existence through Klaus Klein (Marburg). ${ }^{15}$ Late in 2014, Klein had directed Nemes towards an entry by Renate Schipke and Kurt Heydeck in the Handschriftencensus der kleineren Sammlungen in den östlichen Bundesländern Deutschlands from 2000. ${ }^{16}$ This notice - in which Schipke and Heydeck described and characterised Ms. 1361-50, Wartburg-Stiftung Eisenach, as a 'collection of spiritual sayings, legends and teachings of mystics, amongst whom Meister Eckhart' - had escaped the eyes of Eckhart scholarship. ${ }^{17}$ The entry was based on a description of the manuscript, made by Renate Schipke already ten years earlier in 1990, after the Berlin wall had come down and the danger of identified medieval manuscripts being snatched by Alexander Schalck-Golodkowski had gone. ${ }^{18}$ The report, however, had rested unread for a decade at the Wartburg, because in those years further restoration work of the castle, including the archive, had started and not come to an end by 2015. Still, even though Nemes had identified the manuscript, because of the building works at the castle it took a while to get access to the manuscript. Since the first inspection of the manuscript in April 2015, in collaboration between

12 Berlin, Staatsbibliothek Preussischer Kulturbesitz, Ms. germ. fol. 986, 200 ${ }^{\mathrm{vb}}-201^{\mathrm{rb}}$. The Ms. germ. fol. 986 dates from the mid 15th century; Ms. germ. fol. 986 is known to Eckhart scholars since 1940, see Quint 1940, 7-10. According to Nemes, the ms. belongs to a group of mss. with mystical literature from Swabia and Alemannia, which derive from the Charterhouse Buxheim, 15th century, see Nemes 2015, 182-3, n. 15 and his description of this ms. in Manuscripta mediaevalia (online: http://www.manuscriptamediaevalia.de/?xdbdtdn!\%22obj\%2031257534\%22\&dmode;=doc\#|4 [last accessed 21st September 2016], with further literature). On the Munic manuscript, see Schneider 1996, 559.

13 Pfeiffer 1857, IX, n. 15.

14 See Spamer 1909, 313, n. 3. Similar Bray 2013, 483, n. 11 and Gottschall 2013, 535.

15 See for this, and the history of the discovery of the manuscript and its provenience, Nemes 2015.

16 Schipke and Heydeck 2000, 68, n. 66.

17 Ibid. 'Sammlung geistlicher Sprüche, Legenden und Lehren der Mystiker, darunter Meister Eckhart' (own translation).

18 Whether he had or would have touched such manuscripts, I don't know and have not researched; see, however, Blutke 1990. 
Nemes, myself and Julie Casteigt, we have been able to see the manuscript itself and photograph it. Since this time, Nemes and I have worked on the manuscript, and we were soon joined by art historian Beate Braun-Niehr. As a first result, in the beginning of the year 2016, we showed the re-discovered codex to scholars and introduced the public to it during an exhibition that Jutta Vinzent mounted: 'Performing Bodies. Space and Time in Meister Eckhart and in Performances and Video Installations by Taery Kim, 24.01.2016 - 13.03.2016, Galerie Waidspeicher, Erfurt'. ${ }^{19}$ In the same year, we also jointly presented the finding to an audience in the Library at the Stadtbibliothek Weberbach, Trier, on 25th October 2016.

The importance of 'P' had not only been seen by Pfeiffer, but also by Heinrich Denifle and Josef Koch who had identified some of the excerpts, given by Pfeiffer, as redacted translations of Eckhart's Latin, mainly exegetical, works. ${ }^{20}$ Loris Sturlese, therefore, put the redactor amongst those Dominicans of Cologne who, despite the condemnation of some of Eckhart's views in the papal Bull De agro dominico of 1329, continued 'to intensely care for the heritage of the deceased Master for some decades' ${ }^{21}$ Whether or not we are dealing with Dominican students of Eckhart from Cologne who translated Eckhart, or with Eckhart's own translation - alternatives which, as Nemes has rightly pointed out, must not be mutually exclusive - still needs to be researched, particularly as the latter part of the re-discovered codex (the vernacular Quaestio on 'relatio' is contained in this part) has a parallel in another manuscript, preserved in Berlin, as mentioned above. Though the full study of the Wartburg manuscript has begun, it will take a while until we will be able the present a comprehensive account of the new finding. ${ }^{22}$ In what follows, I will only focus on the short vernacular Quaestio on 'relatio', as it provides us with the most concise summary of Eckhart's teaching that relates to monism and dividuality and which I will read against the background of the Latin Quaestiones on 'Relation' and 'Difference' and Eckhart's other works, informed by the successfully submitted $\mathrm{PhD}$ by one of my students, Jana Ilnicka. ${ }^{23}$

19 See http://www.erfurt.de/ef/de/erleben/veranstaltungen/ast/2016/123478.html\#pk_campaign=Redirector-Webcode\&pk_kwd=ef123478 (last accessed 10th April 2017); see also the exhibition catalogue: Vinzent and Wojtulewicz 2016.

20 For this and what follows see Nemes 2015, 181; Denifle 1886, 429-32 and Koch 1963, 148-9.

21 Sturlese 2007a, 131-2. See also Sturlese 2007b, 117: 'Die "Eckhartisten” arbeiteten, als ob die Bulle “In agro dominico” überhaupt nicht existiert hätte.' A survey on the production of spiritual literature in German and Latin during the first third of the 14th century is given by Schubert 2013, 256-60.

22 See for a preliminary report Vinzent 2017.

23 See Ilnicka 2018. 


\section{The question 'On relation' of the Wartburg-Stiftung Eisenach, Bibliothek, Sign. Ms. 1361-50, fol. 87 $-87^{\mathrm{v}}$ and Berlin, Staatsbibliothek Preussischer Kulturbesitz, Ms. germ. fol. $986,200^{\text {vb }}-201^{\text {rb }}$}

Here is the text of this Qaestio, based on these two manuscripts from Wartburg and Berlin ${ }^{24}$ :

\begin{tabular}{|c|c|c|}
\hline Eckhart, On Relation & Own translation & Structure \\
\hline $\begin{array}{l}\text { / } 1 \text { Meister Eghart und ouch ander } \\
\text { meister sprechent } / 2 \text { daz zwei ding } \\
\text { sind in gode: wesen und widersehen } \\
\text { / } 3 \text { daz da heisset relacio: }\end{array}$ & $\begin{array}{l}<1>\text { Meister Eckhart and other } \\
\text { masters too state, that there } \\
\text { are two things in God: being and } \\
\text { reflection, that is called relatio. }\end{array}$ & 'being and relation' \\
\hline $\begin{array}{l}\text { [Contra:] } \\
\text { nu sprechend die meister } / 4 \mathrm{daz} \\
\text { des vader wesen } / 5 \text { den sun in der } \\
\text { godheit niht gebird: }\end{array}$ & $\begin{array}{l}\text { [The counter-argument:] } \\
\text { Now the masters say that } \\
\text { the Father's being in the } \\
\text { godhead does not give birth to } \\
\text { the Son. }\end{array}$ & \\
\hline [Pro:] & [The argument:] & \\
\hline $\begin{array}{l}\text { Wan [da] der vader nach sinem } \backslash \\
\text { [m.r.: wesen] ensiht niht anders } \\
\text { danne in sin bloßes wesen } / 6 \text { und } \\
\text { schouwet sich selber da inne } / 7 \\
\text { nah aller siner kraft / } 8 \text { und da } \\
\text { schouwet er sich blos an den sun } \\
\text { / } 9 \text { und an den heiligen geist: und } \\
\text { sicht da mit dann einkeit sines } \\
\text { selben wesens }\end{array}$ & $\begin{array}{l}<2>\text { If according to his being } \\
\text { the Father has in no other way } \\
\text { insight into his bare being, and } \\
\text { sees himself in there according } \\
\text { to his entire power, he there } \\
\text { sees himself bare without the } \\
\text { Son and without the Holy Spirit, } \\
\text { hence he sees then oneness of } \\
\text { his very being. }\end{array}$ & $\begin{array}{l}\text { bare being, oneness } \\
\text { and sameness }\end{array}$ \\
\hline $\begin{array}{l}\text { Wen aber der vader ein widerschou- } \\
\text { wen und ein widersehen haben wil } \\
\text { / } 10 \text { sin selber in einer ander person } \\
\text { / } 11 \text { so ist des vader wesen in dem } \\
\text { widersehnenne geberend den sun }\end{array}$ & $\begin{array}{l}\text { If, however, the Father wants to } \\
\text { have a regard and a reflection } \\
\text { of himself in another person, } \\
\text { it is the Father's being which } \\
\text { gives birth to the Son in this } \\
\text { reflection. }\end{array}$ & $\begin{array}{l}\text { reflection is consti- } \\
\text { tutive for persons } \\
\text { in God }\end{array}$ \\
\hline
\end{tabular}

24 Text and translation follow the critical edition with German translation by Ilnicka 2018. Some of the following ideas are also based on her PhD. 


\begin{tabular}{|c|c|c|}
\hline Eckhart, On Relation & Own translation & Structure \\
\hline $\begin{array}{l}\text { /12 und wand er im selber in dem } \\
\text { widersehen so wol gauellet / } 13 \text { und } \\
\text { im daz widerschouwen so lustelich } \\
\text { ist / } 14 \text { und wand er alle wollust hat } \\
\text { eweklich gehebt / } 15 \text { darumbe so } \\
\text { muost er / } 16 \text { ouch dis [wist] wider- } \\
\text { sehen }\end{array}$ & $\begin{array}{l}\langle 3\rangle \text { And as he is so delighted } \\
\text { about himself in this reflection, } \\
\text { and the regard is so desirable } \\
\text { for him and as he had such } \\
\text { desire for eternity, therefore he } \\
\text { must have this reflection, too, } \\
\text { for eternity. }\end{array}$ & \\
\hline $\begin{array}{l}<87 v>\text { eweklichen hauen: } \\
\text { darumb so ist der sun ewig als der } \\
\text { vader / } 2 \text { und von dem wolgeuallen } \\
\text { und von der minne / } 3 \text { so vader unde } \\
\text { sun ze samen havend / } 4 \text { so hat der } \\
\text { heilig geist sinen urspring: }\end{array}$ & $\begin{array}{l}\text { The Son is, therefore, as eternal } \\
\text { as the Father, and from the desire } \\
\text { and love as they are enjoyed by } \\
\text { Father and Son jointly, the Holy } \\
\text { Spirit has its origin. }\end{array}$ & $\begin{array}{l}<3>\text { the eternity of } \\
\text { relation }\end{array}$ \\
\hline
\end{tabular}

vnd wan disv minne zwichchen dem vader und dem sun ist eweklich gewesen: darumbe so ist der heilig geist / 5 als ewig als der vader und der sun: und hand die dri person niht wan ein bloßes wesen und sind allein underscheiden an den personen: wan des vaders person ward nie des suns noch des heiligen geistes person: und alle drie $\backslash /$ [m.r.: sind] ein ander vremde an den personen $/ 6$ und sind doch ein in dem wesen

1 ouch < B; 3 da < B; 5 ensihet] sicht Gi2; 9 da mit dann] da niht wan Gi2; 16 ouch] < Gi2; dis] ding B; 2 von der < B; minne] inne B; 4 nun] wan; 5 niht wan] mit denn $B$

\begin{abstract}
Hence, as the love between
Father and Son has existed for ever, therefore, the Holy Spirit is as eternal as Father and Son. And the three persons have only one bare being and are different only with regards to the persons. The person of the Father, namely, was never that of the Son nor the person of the Holy Spirit. And all three are alien to each other with regards the persons, although these are one in being.
\end{abstract}

As the apparatus shows, there are a number of smaller text critical problems with this text, the most difficult being the understanding of 'wan' in $5 .{ }^{25}$ As the following 'Wen aber' in 9 shows, the 'wan', too, has to be read as the start of a condition,

25 The difference in line 9r between niht wan] mit dann is contentwise irrelevant, but simply a variant expression. Line 16r dis] ouch ding might indicate that 'ouch' has dropped out from P. In contrast, in line $2 \mathrm{v}$ one character in B has dropped out of 'minne', so that only 'inne' remained, a phenomenon that we can also see in other places in B, where B seems to leave out characters or even words. Irrelevant with regard to content is also the difference in line $5 \mathrm{v}$ niht wan] mit denn $\mathrm{B}$. 


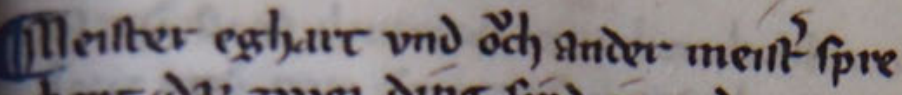
dient das zwet ding find in gove-ivepen

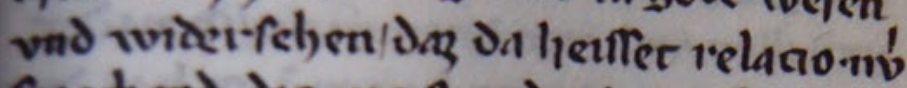

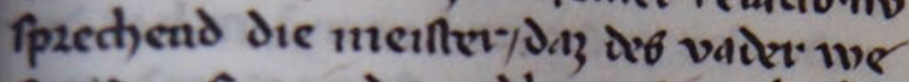

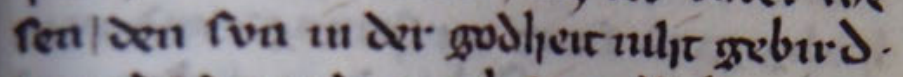

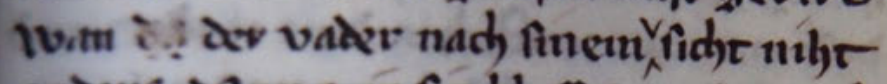
ander danne in fin blores wepen/vad nhöwuer fid felber da inne/ nall, allev finet.

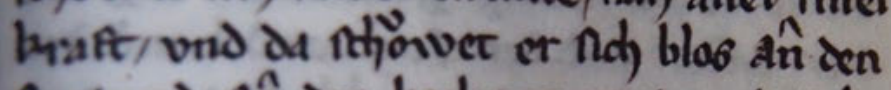
fon/ vnd ấ ien lealigen gent. vnd fidte da mbe wa cunture fines relben mereng

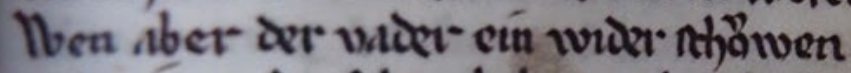
vnd eun widet-reben lyaben wil/ fin relberin ener Audet ptony ro tit des vadi we

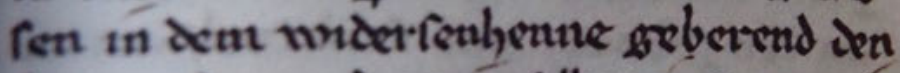
fory ond ruand er in Pelber-in dem wi' revfehen fo nol grauellet wid ím day wi senty oven fo tuftelid) int/vind wand

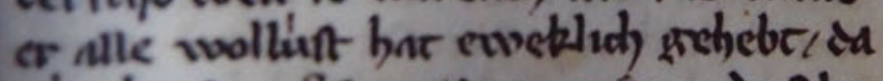
rumbe po munt erjo16 wis widerehen 


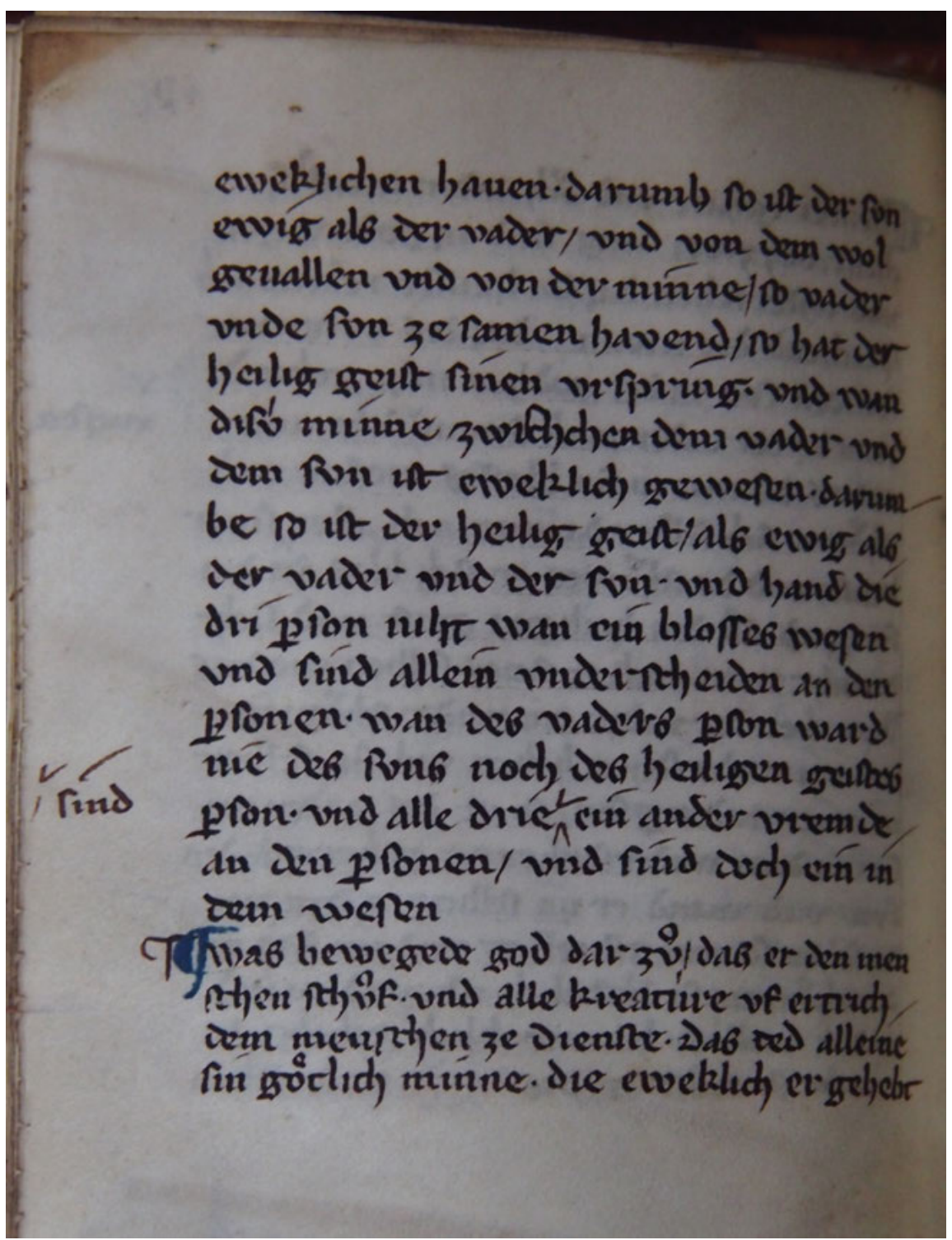

Fig. 2: Wartburg-Stiftung Eisenach, Bibliothek, Sign. Ms. 1361-50, fol. 87². 
Pas an die trat minine mex dormb as ou got da ineme findept Wn

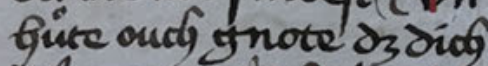
on creatuk icht betzieg dab on ander cat ${ }^{2}$ ich Blibeft on gottes porelft IPlin su weat ares? montef nowisfot die ol ex rounfers mit fü." fichtifait wmo mit orit betracfturnge ind 100 , degnit entit dab voû. ctet onverniunftellicy Nus dab waect gaippent fiegeliagù meate vin $u$ pilicg wovictum fluing et dex bailig gaít aloge. pegriben faut in Sen Bict der woipbait 6 ift ain fange dab of toro yeboret woazd dú linme dipipt min licber fon in desn íct min. voolgya fall of dal vocax des wattexes firmme frie pe.. ection gie maifter az $Q B$ mit vö́ze dez uattez bám. me mex eb naiac allain ain offerbazung a $_{3}$ deb vatter ze fegen waike?
Mock ou tube wovic òc. mit der bailig you't mex eb vaciz am offor. bazung Deb bailigen. caifab a paipter og uns ander maipeas pprectient a 33 woaij di ng find 'm got weps mons widexplen dab da baipper celacio ka proudent die maifé Lab deb uatteab woefy de fun in der got fait mie yebinct poan dor wattex naùd finc we en enfifet mit ans's ben in Im Hloper we

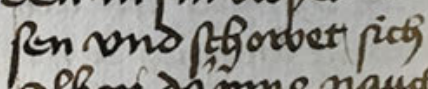
plbex da mine naus allex f'́mex keafte on sa peqowet ex cidg blop and den fon pris àn doen bailgon gaíf on ficfet da mit acts aim tait in pelber wor panto Noan abee seac ualtex aim ravideack foncoe on com widuefecten babe wilf in pllecim ám andien of on piftes vatezb wefen in de

Fig. 3: Berlin, Staatsbibliothek Preussischer Kulturbesitz, Ms. germ. fol. 986, $200^{\text {v }}$. 

wider plyenc graper

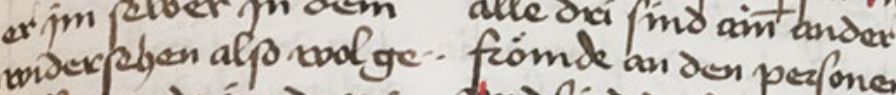

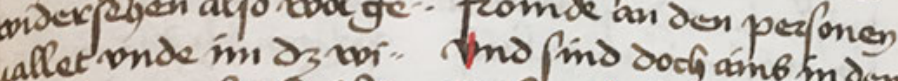

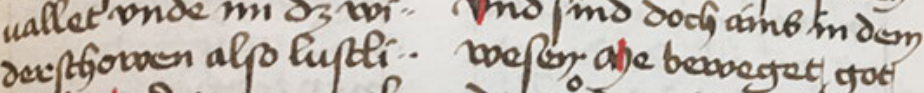

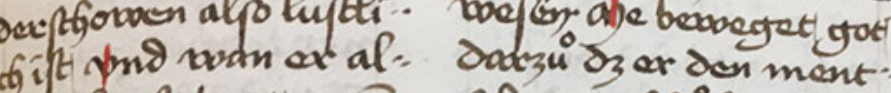
le twolnuft gaut eave. flich gelgept axarm pomift er ours oing widecection coventl. iffen Gaben qaemb pift aec fun evoig alb ber vattar pona vio de wolgeuallen and $\vec{m}$. ne puatter vno fin 3c amen babent polyt seck bailig gaift me by paung yns wan difu nime zwiftect dem natter $1 \mathrm{~m} 9 \mathrm{dm}$ fun ift excetich ge: wejh dacem pits fallig gaift als cavigg alb der ualter on dor fun ina gänd die azä" fon prit asy a im blo. ter acen uno fins Llaim undaptaises an den pponen yoan suatterop pon wass सten gुaptif ons alle tat uf cutrich de men. the en ze dienple aztatt allain fón göthic mine ric ar exrentlicy baut ge. Gebet zuiden ment ptos und andeas mit $\$$. been Gazt praíctet rie befter raipe die ám menthe ta." beh mug got ze viency az yt dz Dermentfle im

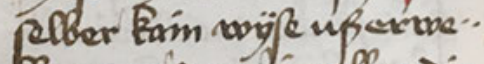
He mex szerin delonoi. ngen die in got 3 if fing. at ylicgpte $2 m$ g got dax. íme piege nocts rerme. neflace en pl mit preotin itg wil got alp arienom ods alp ode alpo du plt prection base itg emoil baede rip noch rabnince. ich wil onic rienasim al. len aingen die ou min zi fügept opan idy oítg.

Fig. 4: Berlin, Staatsbibliothek Preussischer Kulturbesitz, Ms. germ. fol. 986, 201' ${ }^{\text {. }}$ 
not a cause. Only this, then, gives the text the proper structure of a Quaestio instead of a 'Saying', as it has been read in Pfeiffer '(Saying 34)'. The question opens with reference to 'Meister Eckhart and other masters'. Eckhart and other masters agree on the position that 'there are two things in God: being and reflection', the latter being called 'relatio'. ${ }^{26}$ The difference, however, between those other masters and Eckhart is introduced by the counter-argument 'now' ('nu'). These masters reject the idea that it was the Father's being that gave birth to the Son in the Godhead, a view that Eckhart tries to substantiate and explicate in this question. Indeed, he has explicitly stated this view in his Commentary on Exodus: 'The power to generate in the Father is in the essence rather than in paternity', ${ }^{27}$ hence God, the Father, does not generate the Son out of God as Father, but out of the essence of the Father, as God or Godhead. Unlike Bonaventure and Thomas, as I have shown elsewhere, ${ }^{28}$ Eckhart does not focus on 'fatherhood' as the personal property of the Father; instead, fatherhood expresses the relation between Father and Son. Although the relational nature of fatherhood is an idea which can also be found in Thomas, Eckhart stresses that the Father generates the Son insofar as he is God, in his divine nature, which is the reason why God as the agent also communicates his power to generate to the Son without turning the Son into the Father. For Eckhart, the Son is not only the generated one in contrast to the ingenerated Father, he is, like the Father, the generating God.

Already in his Sermones et Lectiones super Ecclesiastici, homilies and lectures on Jesus Sirach, the Meister noted the broad theological tradition, against which he developed his revolutionary view. Just like a self-defeating understatement he starts with the admission that the 'saints and doctors say rightly that in the Godhead the essence does not generate. Unanimously, the doctors also say that the power to generate is not an absolute power, but an essence together with

26 This position is, indeed, one of Eckhart's views as can be seen by Eckhart, $\operatorname{Pr} .9$ ( $D W$ I 147, 5-8): 'The first [category] that has most of being from which all things take in being, that is substance, and the last [category] which has the least of being, that is called relation, this is equal to the greatest in God which has most of being' ('Diu êrste, diu des wesens allermeist hât, dâ alliu dinc wesen inne nement, daz ist substancie, und daz leste, daz des wesens aller minnest treit, daz heizet relatio, daz ist glîch in gote dem aller grœsten, daz des wesens allermeist hât').

27 Eckhart, In Ex. n. 28 ( LW II 34, 1): 'Potentia generandi in patre est essentia potius quam paternitas', and he refers to Thomas Aquinas, S. theol. I q. 41 a. 5: 'Potentia generandi significat in recto naturam divinam, sed in obliquo relationem (scilicet paternitatem)'. The Divine essence as the power or potentiality for fatherhood of the Father - with the simple and clear difference between on the one side 'the essence and its potentiality without personality', and on the other the divine 'person' - is expressed in another complex but highly important homily which stems with all likelihood from Eckhart's pen; see Eckhart On Romans 11:33 in Jostes 1895, n. 19, p. 15, 28-32).

28 Vinzent 2012. 
a relation. ${ }^{29}$ When we compare the latter statement, we see the parallel to the opening of Eckhart's vernacular Quaestio.

Already earlier Eckhart had expounded the argument that there are only two categories in the Godhead, namely essence and relation, and that 'the essence as essence does not diffuse itself, because it is directed towards its inner self, not towards something else, and because it belongs to itself and is through itself, is namely always one in the Godhead'. Hence, essence and relation, as the two categories in God, make God the one who generates. But he adds that it is a 'tricky question' which of the two, the essence or the relation, comes first. ${ }^{30}$ In his work on Jesus Sirach, he seems to agree with Bonaventure, saying that 'it seems necessary that the relation is the reason for bearing fruits and for diffusion in the Godhead .., namely the Father does not speak the Word, nor generates the Son insofar as he is essence or substance, but insofar as he is principle .., and the principle, as the term "first" indicates, implies relation of order and origin. ${ }^{31} \mathrm{~A}$ close reading of this passage, however, indicates that Eckhart is already moving beyond the saints and the masters, especially Bonaventure and Thomas, because he does not assert that the Father generates the Son, insofar as he is Father, the relative to the related Son, but insofar as he is principle, implying Eckhart's own understanding of principle. Eckhart endorses this difference by adding that according to the Liber de causis it is not said that the first (in masculine form, primus) 'is rich in itself', but that the neuter first (primum) 'is rich in itself', ${ }^{32}$ so that it is God - and not the Father - who with regard to the relation in him generates, just as it is God in his essence, yet not in his essence qua essence, but in his essence with relation, who generates the Son and creates all creatures. By using the Liber de causis, Eckhart is correcting both Bonaventure and Thomas. In addition to this, Eckhart is then solving the mentioned tricky question in his Commentary on John that in the Godhead, wherein are only essence and relation, 'the power to generate [...] directly and more principally belongs to the essence rather

29 Eckhart, In Eccl. n. 11 (LW II 241,1-3): 'Propter quod optime dicunt sancti et doctores quod in divinis essentia non generat. Dicunt etiam doctores communiter quod potentia generandi non est absolute, sed essentia cum relatione.'

30 Eckhart, In Eccl. n. 11 (LW II 241,3-4): 'Quid autem principalius, nodosa quaestio est.'

31 Eckhart, In Eccl. n. 12 (LW II 241,5-242,1): 'Oportet igitur necessario quod relatio sit, ratione cuius est fecunditas et diffusio in divinis ... pater enim non dicit verbum nec generat filium, in quantum essentia sive substantia, sed in quantum principium . . Principium autem, sicut et li primum, relationem importat ordinis et originis.'

32 Eckhart, In Eccl. n. 12 (LW II 242,1-3): 'In De causis enim dicitur: 'primum est dives per se'. 'Primum' ait, non primus, quia ratione relationis sive ordinis habet deus diffusionem sive fecunditatem tam in divinis quam in creaturis.' 
than to the relation that is paternity'.33 Cutting a long thought process short, we can conclude that Eckhart is consciously moving away from the authority of previous masters and places the trinitarian generation, indeed, into the Godhead of the Father, into his being, though understood as a being with relation.

The same concept of a generation of the Son through the Father's essence, God and Godhead, we find in Eckhart's Latin Parisian Question VII. In this Quaestio, Eckhart addresses again the topic of power and paternity. The problem here is whether 'the Father generates through fatherhood, because', as some say, 'through it [fatherhood] he [the Father] is constituted in his being' - or whether the Father generates his Son through his divine essence, his nature, because it is not fatherhood that is the principle, but divine essence or nature. Eckhart gives his answer with reference to John Damascene - 'Generating is the work of nature' the same reference Eckhart used in his second commentary on Genesis, borrowed from Thomas Aquinas. ${ }^{34}$ Here, in this Question, however, Eckhart deduces from Damascene the same anti-Bonaventuran and anti-Thomasian solution which we have already encountered before in Eckhart: it is divine essence that is the principle and the essence makes the Father a father with his fatherhood. Not fatherhood or paternity, but God's essence, being or nature (qua relation, of course) is the principle of generation; paternity is the Father's property, while Father is the expression of an essential relation and a relational Godhead. Eckhart draws exactly the same conclusion as we have found in his commentaries: because the Father generates out of divine essence, God communicates the power to generate to his Son without turning the Son into the Father. ${ }^{35}$

\section{Being and dividualism}

The present short vernacular Quaestio, as we will see, provides not only a short introduction, but is also a concise summary of Eckhart's teaching on God's self-constitution, hence is a lens through which we can read how he conceptualises a first principle that has to be understood not as a monistic, single primary force, but as a dynamic dividual.

33 Eckhart, In Ioh. n. 43 (LW III 36,4-5): 'Potentia generandi in divinis in recto et principalius convenit essentiae quam relationi, quae est paternitas'; id., Pr. 103 (p. 336 Pfeiffer).

34 See Eckhart, In Gen. II nn. 44-5; 185 (LW I 512,3-14; 656,11-2), where it is even applied to the generation of creatures.

35 Eckhart, of course, goes even further and thinks of God communicating this power to his creation; see Pr. 100 (DW 4/1, 277,47-278,61). 
First, Eckhart deals with the potential idea of the Father's 'bare being', his Godhead, which is the Father's divine being in a pre-relational sense, hence the Godhead's being prior to any trinitarian constitution of persons and, therefore, prior to any relation.

$<2>$ If according to his being the Father has in no other way insight into his bare being, and sees himself in there according to his entire power, he there sees himself bare without the Son and without the Holy Spirit, hence he sees then oneness of his very being.

To Eckhart, a pre-relational principle ('Father'), that searches for itself, cannot lead to self-reflection, but only to a sheer seeing of oneness of bare being. As this principle is conceived not in a relational sense, but as bare pre-relational being, the Father is unable to see the Son and the Holy Spirit, but even worse, he even does not see himself. Hence he is without self-reflection, self-understanding, without self. The following conditional phrase underlines this reading of the passage, as Eckhart moves to the next thought of a Father who longs for self-reflection:

If, however, the Father wants to have a regard and a reflection of himself in another person, it is the Father's being which gives birth to the Son in this respect.

This longing of the Father to see himself in a self-reflection leads to no other 'know yourself' than to a giving 'birth to the Son in this respect'. Seeing himself means that the Father is birthing the Son. Of course, these two 'steps' are not chronological events, but purely epistemological and conceptual discernments.

This is not an easy text. The statement seems to carry two important arguments. In the first conditional clause, Eckhart assumes, from the beginning, that according to the Father's being and his Godhead as first principle he would be an entirely monistic entity, if he were not fundamentally dividual and relationally structured, longing to see himself and with himself everything else. That is why he states in a first clause that if the Father had insight into his being - if we assumed a monistic first principle - this resulted in nothing but a brutal facing of purity and bareness of being, not in self-reflection or knowledge. This is even true if we conceived that the first principle were using its entire power: the Father still would see nothing but oneness, neither himself, nor the Son nor the Holy Spirit. The 'exclusively', or better 'barely' ('blos'), picks up on the 'bare being' ('bloßes wesen'): indicating that in the reaching out by the Father for his being and for himself, the assumption of a monistic principle, is futile. This explains that neither the Father's seeing into his pure and bare being, nor his looking for himself gives him a satisfactory self-reflection. He only sees a bare being. This interpretation, then, fits the concluding section that the Father 'does not see 
anything but oneness of his very being'. Any introspection of the Father according to his Godhead and into his being, and even his essentially non-monistic reaching out for himself, ends not in a self-disclosure, self-discovery, or self-consciousness, as we would put it in contemporary terms. All that the Father sees is oneness; he does neither see himself as Father, nor does he see himself at all as self, but all he sees is oneness and sameness of his being, not even unity. As we will see in the next paragraph - such oneness and sameness of the Father's being excludes him being a person, and equally excludes the Son and Holy Spirit being persons. As a result, in such oneness and sameness there would be no 'relation', but only pure substance.

As a consequence of the rejection of such a monistic essentiality of the first principle, Eckhart develops the idea of the Father's longing.

As indicated, though Eckhart speaks of three, we are not able to call the three a Trinity of selves, as even the Father has no self as long as he is only looking at himself and seeking himself. Turning to him as Father, he is more being than Father, more Godhead than God. His act of seeing does not make him an agent. Neither, however, is being itself an agency. Being does not see being, and this is why Eckhart speaks of the Father as the one who has to reach out not for himself and his being, but for 'a regard and a reflection of himself in another person'.

Of course, one may ask at this point, why would the Father - who is all being, pure being, bare being - wish to be anything else? Can one be more than being? What seems tautological, paradoxical or perhaps even nonsensical, Eckhart has discussed in another text, not much easier than the opening of this present Quaestio. In his Predigt 67 Eckhart describes spiritual nature, i.e. the nature of angels and of the human soul, and he speaks about their essential oneness with God:

In all things spiritual one finds that the one is in the other as one and undivided. Where the soul is in her bare nature, detached and separated from all creatures, she would have in her nature, by nature, all the perfection and all the joy and delight that all the angels have without ${ }^{36}$ number and without multitude by nature: I have them fully with all the perfection and with all their joy and all their happiness, as they themselves have them in themselves; and everything I have in me distinctly, as I have myself in myself, irrespective of another, because no spirit excludes [Sturlese: includes] the other. The angel is not included in the soul; therefore it gives itself entirely to each soul, without hindrance from another and God Himself. Not only by nature, indeed: in nature, my soul rejoices in all the joy and all happiness, which God Himself rejoices in His divine nature, may He like or dislike it; because there, there is nothing but one, and where there is one, there is everything, and

36 Quint and Sturlese here read: 'with'. 
where there is everything, there is one. This has some truth. Where the soul is, there is God, and where God is, there is the soul. And if I told you that this were not so, I would say the wrong thing. ${ }^{37}$

Being 'in the other as one and undivided', in 'bare nature', but 'detached' and 'separated from all creatures', all spritual things are one, which is God's oneness. The spirituals' oneness has to be conceptualised just like God's oneness, as a full communication. As 'communication' already indicates - and the soul's joy and happiness support this - this is an exalted state where there is union between the soul and God. And yet, as Eckhart will add, it is not the highest state that the soul can achieve. There is more than being one with God, there is more than joy and happiness for the soul. Although detached from all creatures, the soul in her communication with God still enjoys herself as self.

Now listen to me! There, above, she first grasps the pure absolûciô of the free being, that there is without a 'there', where she does neither take nor give; she is the bare beingness which is deprived of any being and all beingness. There she grasps God nakedly according to the ground, where He is beyond all being. If there still were being, she would take being into being; but there is nothing but one ground. This is the supreme perfection of the Spirit, to which one can get in this life in the way of the Spirit.

But this is not the greatest perfection that we shall ever possess with body and with soul, that the outer person will be fully held in having a substantiated personal being. ${ }^{38}$

With his 'now listen to me!' Eckhart often introduces one of his novel ideas ('nova et rara'). Speaking about the soul, he mentions the pure detachment of the free being, giving us one of the rare Latin equivalents for this core notion of his: absolutio. It is a state of the soul where she is even beyond unity with God, beyond joy and happiness, in a state where she 'neither take[s] nor give[s]'. As in our Quaestio, this state is called 'bare beingness' ('blôze isticheit').

In his commentary on this Predigt 67, one of the most difficult and equally most fascinating texts of Eckhart, Dietmar Mieth has pointed out ${ }^{39}$ that in this text the 'higher' being, the essential oneness with God, is not called the 'best' being. This differentiation makes one wonder: how can one amplify or intensify the 'higher' being? And what could be better than being one with God? What else than the essential oneness could be better for God as for the person, and what else could be the highest aim for both? Thus, again and again this highest aim was invoked by the neoplatonic teachers of the redditio and by the Christian fathers

37 Predigt 67 (DW III 129-30) (own trans.).

38 Ibid. 133-4.

39 Mieth 2017b. 
in the teaching of the Visio beatifica. In his homily, Meister Eckhart explains that the pure spiritual being of angels might be higher than the bodily-spiritual being of humans, because the angel through its pure spirituality is unlimited and united with the divine being; however, so Eckhart, the personal being of human beings is better, even 'the best perfection', not only for human beings, but even for God himself. Why is this? God is only 'self', when he is a person, and this is precisely the kind of being that God chooses for himself. Personality, being with a partner, being Father with a Son, with the Spirit, with the creatures, being of the god-human nature of Christ, being self as non-monistic principle, being as principally dividual is the highest form of being. This self, as we will see, is the foundation both for God as it is for humans. In his vernacular Question, Eckhart continues:

$<3>$ And as he is so delighted about himself in this reflection, and the regard is so desirable for him and as he had such desire for eternity, therefore he must have this reflection, too, for eternity. The Son is, therefore, as eternal as the Father, and from the desire and love as they are enjoyed by Father and Son jointly, the Holy Spirit has its origin. Hence, as the love between Father and Son has existed for ever, therefore, the Holy Spirit is as eternal as Father and Son. And the three persons have only one bare being and are different only with regards to the persons.

Eckhart highlights the joy and delight about this highest state of being 'in this reflection', whereby 'reflection' is the translation of 'widersehnenne', which could also be rendered as self-reflection, or self-regard ('widerschouwen'). The emotional terms used here (delight, desirable, desire, love) indicate that Eckhart is not only writing about a purely intellectual or ontological level of epistemology, but that it is a fully embodied view of being and self. The first principle's will - pars pro toto for any longing for self - only results in satisfaction and a full realisation of 'self', if such self - from the first principle to the last principled is conceived of as dividual: as a self that only in the birthing of other selfs can become what is its highest being, namely self. Self, as understood by Eckhart, is only a dynamically productive self by birthing the other not as a dependent, hierarchically subjugated other, but as a full and own self which in return becomes the birthing self of the principle self. Hence, the such conceived and birthed self is itself just like the first principle itself: a first, conceiving and birthing principle. Within this dynamically productive process of self-becoming there is no hierarchy between the selfs. They are only selfs as mutually birthing selfs which, if we compare Eckhart's view to concepts of self-production in, for example, Idealism, are not evolutionary, nor teleologically or hierarchically conceived. To Eckhart there would be no 'single primeval force' that powered the big bang or any big bang, but the primeval force would be itself the result of a powering big bang or rather of powerful forces and big bangs. 


\section{References}

Blutke, Günter. 1990. Obskure Geschäfte mit Kunst und Antiquitäten. Ein Kriminalreport. Berlin: LinksDruck Verlag.

Bray, Nadia. 2013. 'The Reception of Meister Eckhart in 14th-Century Germany'. In A Companion to Meister Eckhart, ed. Jeremiah M. Hackett. Brill's Companions to the Christian Tradition 36, Leiden/Boston: Brill. 481-508.

Denifle, Heinrich. 1886. 'Meister Eckeharts lateinische Schriften und die Grundanschauung seiner Lehre', Archiv für Literatur- und Kirchengeschichte des Mittelalters 2. 417-652.

Gottschall, Dagmar. 2013. 'Eckhart and the Vernacular Tradition: Pseudo-Eckhart and Eckhart Legends'. In A Companion to Meister Eckhart, ed. Jeremiah M. Hackett. Brill's Companions to the Christian Tradition 36, Leiden/Boston: Brill. 509-52.

Ilnicka, Jana. 2018. Meister Eckharts achte Pariser Quästion in der zeitgenössischen Diskussion zu Relatio an der Universität zu Paris 1300-1320, Diss. Universität Erfurt.

Jostes, Franz (ed). 1895. Meister Eckhart und seine Jünger. Ungedruckte Texte zur Geschichte der deutschen Mystik. Freiburg (Schweiz): Commissionsverlag der Universitaetsbuchhandlung.

Koch, Josef. 1963. 'Meister Eckharts Weiterwirken im deutsch-niederländischen Raum im 14. und 15. Jahrhundert', La Mystique Rhénane. Colloque de Strasbourg 16-19 mai 1961. Travaux du Centre d'Études Supérieures Spécialisé d'Histoire des Religions de Strasbourg. Paris: Presses universitaires de France. 133-56.

Maurer, Armand A. 1974. Master Eckhart: Parisian Questions and Prologues, translated with an introduction and notes. Toronto: Pontifical Institute of Mediaeval Studies.

Meister Eckhart. 1936-. Die Lateinischen Werke, eds. Ernst Benz et al. 5 vols. Stuttgart: Kohlhammer. Mieth, Dietmar et al. (eds.). 2017a. Meister Eckhart in Paris and Strasbourg. Eckhart: Texts and Studies 4. Leuven: Peeters.

Mieth, Dietmar. 2017b. 'Predigt 67 “Deus caritas est”'. In Lectura Eckhardi IV : Predigten Meister Eckharts von Fachgelehrten gelesen und gedeutet, eds. Georg Steer et al. Stuttgart: Kohlhammer. 95-121.

Nemes, Balázs J. 2015. 'Meister Eckhart auf der Wartburg. Fundbericht anlässlich der Wiederentdeckung einer frühen Eckhart-Handschrift aus dem Prämonstratenserinnenstift Altenberg im Bestand der Wartburg-Stiftung', Wartburg-Jahrbuch 24. 176-202.

Pfeiffer, Franz (ed.). 1857. Deutsche Mystiker des vierzehnten Jahrhunderts. Bd. 2: Meister Eckhart. Leipzig: Vandenhoeck \& Ruprecht.

Quint, Josef. 1940. Neue Handschriftenfunde zur Überlieferung der deutschen Werke Meister Eckharts und seiner Schule. Ein Reisebericht. Meister Eckhart. Untersuchungen 1. Stuttgart: Kohlhammer.

Rees, Martin. 1997. Before the beginning. Our universe and others. London: Simon \& Schuster.

Rees, Martin. 1999. Just six numbers: the deep forces that shape the universe. London: Weidenfeld \& Nicolson.

Schneider, Karin. 1996. Die deutschen Handschriften der Bayerischen Staatsbibliothek München. Die mittelalterlichen Handschriften aus Cgm 4001-5247. Catalogus codicum manuscriptorum Bibliothecae Monacensis V 7. Wiesbaden: Harrassowitz. 557-65.

Schipke, Renate and Kurt Heydeck (eds.). 2000. Handschriftencensus der kleineren Sammlungen in den östlichen Bundesländern Deutschlands. Bestandsaufnahme der ehemaligen Arbeitsstelle "Zentralinventar mittelalterlicher Handschriften bis 1500 in den Sammlungen der DDR» (ZIH). Staatsbibliothek zu Berlin - Preußischer Kulturbesitz. Kataloge der Handschriftenabteilung. Sonderband. Wiesbaden: Harrassowitz. 
Schubert, Martin. 2013. ‘Köln'. In Schreiborte des deutschen Mittelalters: Skriptorien - Werke Mäzene, ed. idem. Berlin: de Gruyter. 217-61.

Spamer, Adolf. 1909. 'Zur Überlieferung der Pfeiffer'schen Eckeharttexte', Beiträge zur Geschichte der deutschen Sprache und Literatur 34. 307-420.

Sturlese, Loris. 2007a. 'Die Kölner Eckhartisten. Das Studium generale der deutschen Dominikaner und die Verurteilung der Thesen Meister Eckharts (1989)'. In Homo divinus. Philosophische Projekte in Deutschland zwischen Meister Eckhart und Heinrich Seuse, idem. Stuttgart: Kohlhammer. 119-35.

Sturlese, Loris. 2007b. 'Meister Eckharts Weiterwirken. Versuch einer Bilanz (1992)'. In Homo divinus. Philosophische Projekte in Deutschland zwischen Meister Eckhart und Heinrich Seuse, idem. Stuttgart: Kohlhammer. 107-18.

Sturlese, Loris. 2011. 'Magistri Echardi Quaestiones Parisienses. Supplementum', Meister Eckhart. Die deutschen und lateinischen Werke. Die lateinischen Werke. Band I,2.7-9. Lieferung. Stuttgart: Kohlhammer. 453-69.

Sturlese, Loris (in collaboration with Walter Senner and Markus Vinzent). 2015. 'Pariser Quästionen VI-IX', Meister Eckhart. Die deutschen und lateinischen Werke. Die lateinischen Werke. Band I,2. 10-13. Lieferung. Stuttgart: Kohlhammer. 715-26.

Vinzent, Jutta and Christopher M. Wojtulewicz (eds.). 2016. Performing Bodies Time and Space in Meister Eckhart and Taery Kim. Eckhart: Texts and Studies 6. Leuven: Peeters.

Vinzent, Markus. 2012. 'Questions on the attributes (of God): Four Rediscovered Parisian Questions of Eckhart', Journal of Theological Studies 63.156-86.

Vinzent, Markus. 2015. 'Omnipotence between Duns Scotus and Meister Eckhart', Archa Verbi 13. 455-74.

Vinzent, Markus. 2016. 'Eckhart on Space and Time'. In Jutta Vinzent and Christopher M. Wojtulewicz (eds.). 49-63.

Vinzent, Markus. 2017. 'Eckharts deutsche Übersetzung seiner lateinischen Bibelkommentare', Meister-Eckhart-Jahrbuch 11. 219-58.

Wojtulewicz, Christopher M. 2017. Eckhart on the Principle: an analysis of the principium in his Latin works. Eckhart: Texts and Studies 5. Leuven: Peeters. 